\title{
Phanerozoic continental crust evolution of the Inner Caucasian Microplate: The Dzirula massif
}

\author{
1 Institute of Earth Sciences at the Ilia State University, Tbilisi, Georgia. E-mail:Okrostsvari@gmail.com \\ 2 Cardno ENTRIX, Los-Angeles, USA.
}

In the Pre-Alpine Dzirula massif of the Inner Caucasian Microplate is coded a wide spectrum of the geodynamic and magmatic events taking place in the region and that's why it represents important and major structure for general geological interpretations. In the given work, on the example of the mentioned crystalline massif evolution are considered processes of the continental crust in Phanerozoic collisional orogens. We consider, that in Variscan consolidation Dzirula massif formations of the Neoproterozoic Pan-African tectonicthermal events are observed, that are organically involved in the evolution processes of the Caucasian Phanerozoic collisional orogen and their role in these processes are probably caused by the migration of lithospheric residues to the north, that are formed as a result of Gondwana northern edge Late Ordovician destruction and opening of Palaeo-Tethys. Within the Dzirula massif, a Gondwana-derived Neoproterozoic gneiss-migmatite complex is situated obductively on ensialic island arc. In this Variscan collision-accretion structure, the crustal thickening and released water caused partial melting of the ensialic island arc, thus generating the granitoid melt, which intruded the overlying gneiss-migmatite complex. By the end of this process, the Dzirula massif resembled typical Phanerozoic continental crust.

\section{Introduction}

The Neoproterozoic marks the onset of modern plate tectonic systems (Stern, 2008), and as such the crust-forming processes preserved from the Pan-African evolution of Gondwana records this critical time period. The early tectonic history is frequently overprinted by younger events, but some of these areas are exposed in basement uplifts within the Alpine orogenic belt. The Dzirula massif in the central part of the Inner Caucasian Microplate in the Republic of Georgia is one of these windows. It exposes pre-Alpine basement, and contains a wide range of granitoids of different pre-Alpine ages. Geochemical and geochronological data provided in this paper helps shed light on crust-forming processes and geodynamics in this critical age range.
Most continental crust was formed from mantle-derived magma before Late Proterozoic, and most intensively in the interval of 3.22.5 Ba (Taylor and McLennan, 1985) when the earth's crust was divided into granulite-basic and granulite-gneissic. Crust formation at the end of Proterozoic and the Phanerozoic occurred as a result of lithospheric thickening, and granite-forming processes were localized at subduction zones. Here the continental crust was formed as a result of lateral and vertical accretion of island arc complexes at active continental margins or by mantle-derived magmatic additions. The application of integrated isotopic studies of $\mathrm{Nd}, \mathrm{Sr}$, and $\mathrm{Ar}$ isotope systematics in the North American Cordillera (Allegre, Ben Othman, 1980; DePaolo, 1981; DePaolo et al., 1991; Samson and Patchett, 1991) in Lachland orogen in the Eastern Australia (Collins, 1998); in Meguma lithotectonic zone in the NE Canada (Clarke et al., 1992); in central Asia (Jahn et al., 2000); in the Shyok-Darbuk corridor of NE Ladakh, in India (Daga et al., 2010) have largely supported this view of crustal formation.

The Pre-Alpine consolidation Dzirula massif is a good example of Phanerozoic lithospheric thickening and continental crustal formation. It is located in the North side of the Caucasus Orogen and represents a complicated and the widest outcropped part of the PreAlpine crystalline basement. As a result of the collision and of generation new magmatic centers Neoproterozoic granite-migmatite complex and ophiolites, Cambrian tonalites, Late Paleozoic microcline granites and Triassic orthoclase gabbros (ricothites) were gathered within the borders of the Dzitula massif. In the pre-Cambrian crystalline schist structure and as well as in composition of Phanerozioc magamtites reflects the whole deformation and the new magmatic center generation processes. The significant part of the regional geological events, starting from the Neoproterozoic up to Alpine, it is clear that in the structure and composition of this massif is encoded. It therefore Dzirula massif represents an important object for investigation of Proterozoic to Phanerozoic continental crust evolution. Although well-mapped, there are few isotopic or geological studies of the area (Okrostsvaridze and Clarke, 2003, 2004; Zakariadze et al., 1998). We use these geochemical constraints to further constrain the geodynamic and continental crust-forming processes in this area.

\section{Tectonic setting}

The Caucasus represents the Northern segment of the Eastern Mediterranean orogen, which is expended over $1200 \mathrm{~km}$ between the Black and Caspian Seas, at the NW-SE direction. Currently it is an expression of continental collision between the Arabian and Eurasian lithospheric plates and its location represents the connecting segment between the Alpine and Himalayan mobile belts. Three major unites are distinguished Structurally in the Caucasian Construction: the 
Greater and Lesser Caucasian mobile belts and the Inner Caucasian Microplate.

Paleomagnetic and palaeochemical as well as geological data indicate that within the oceanic area of Tethys, which separated AfroArabian and Eurasian continental plates, there were relatively small continental or subcontinental plates (terranes) having various geodynamic and geological histories (Gamkrelidze, 1997; Stampfli et al., 2002). During the Late Precambrian, Paleozoic and Early Mesozoic, these terranes underwent horizontal displacement within the oceanic area of Proto-Paleo- and Meso-Tethys, followed by accretion and ultimately merging with the Eurasian continent. The Arabian and Eurasian lithospheric plates are separated by the Greater Caucasian, Black Sea-Central Transcaucasian, Baibut-Sevanian (Lesser Caucasian) and Iran-Afghan terranes (Gamkrelidze, 1997), which in the geological past represented island arcs or microcontinents (Figure 1). The Black Sea-Central Transcaucasian terrane now is situated between the Greater and Lesser Caucasian mobile belts and we consider it as the Inner Caucasian Microplate.

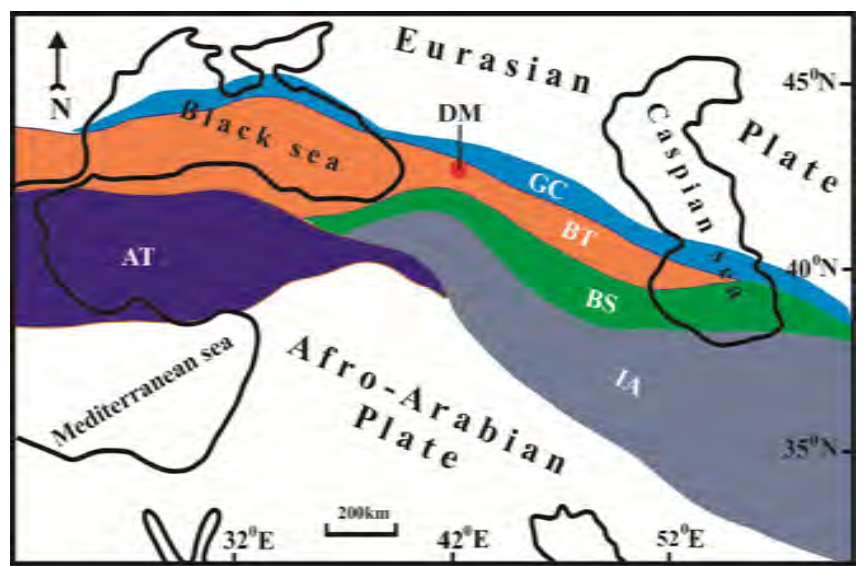

Figure 1. Tectonic zoning of the Caucasus and adjacent area on the basis of the terrane analysis (After Gamkrelidze, 1997). Terranes: GC - Greater Caucasian, BT - Black Sea-Central Transcaucasian, BS - Beiburt-Sevanian, IA - Iran-Afganian, AT - Anatolian. DM - Dzirula massif.

The Inner Caucasian Microplate consists of a pre-Alpine crystalline basement, exposed in the Dzirula and Khrami massifs, that is overlain by an Alpine, non-metamorphosed and moderately folded, nearly $10 \mathrm{~km}$ thick through Meso-Cenozoic volcanosedimentary cover. The Dzirula massif reflects much wider and more interesting spectrum of geological processes, due to that we decided to study it.

\section{Brief geological survey}

The Dzirula massif is exposed in the northen part of the Inner Caucasian Microplate and occupies nearly $1200 \mathrm{~km}^{2}$ at the current of erosion level (Figure 2). It is mainly constructed by Neoproterozoic plagiomigmatites, crystalline schists, and quartz-dioritic gneisses and ophiolites (gneiss-migmatite complex); Cambrian tonalities and granodiorites; Late Paleozoic anatectic microcline granites; and Late Triassic hybrid orthoclase gabbros (rikotites).

Most of the Dzirula massif is composed of the gneiss-migmatite complex. Its protolith was represented by crystalline schists, plagiogneisses and plagiomigmatites, which underwent the

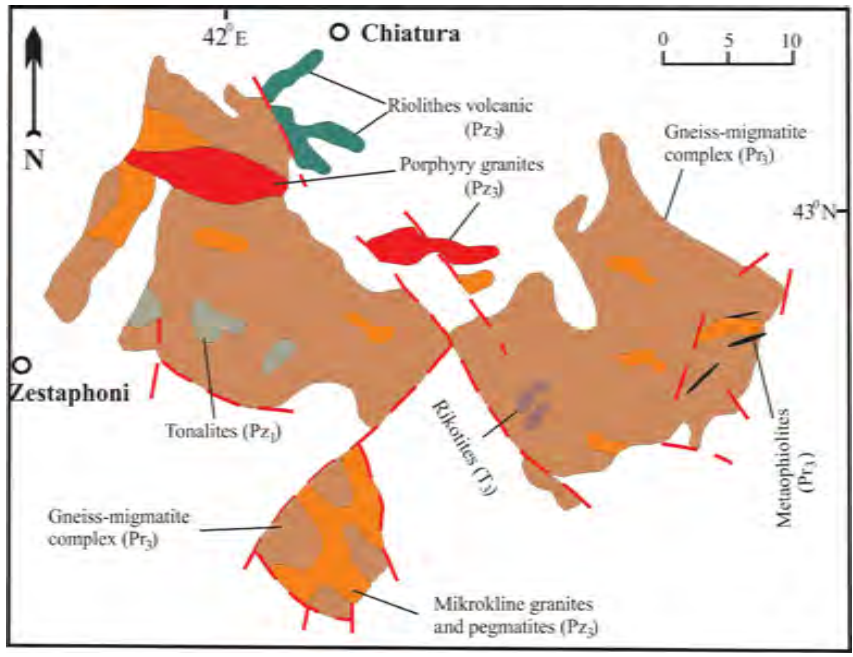

Figure 2. Schematic geological map of the Dzirula massif of the Inner Caucasian Microplate.

Grenvilian regional metamorphism. The wrinkled restites of these rocks, the size of which ranges between one to tens of meters, are found in the Neoproterozoic quartz-dioritic gneisses. Most are represented by metapelites, which underwent regional metamorphism to biotite-muscovite-gneiss, biotite-sillimanite-orthoclase and lowtemperature garnet-cordierite-orthoclase facies (Gamkrelidze, Shengelia, 2005).

In the Cambrian, during Pan-African tectonic-thermal events, several tonalite composition bodies were generated in the gneissmigmatite complex. Later, in the Upper Paleozoic Variscan tectonicthermal events, numerous intrusions of microcline granites were emplaced, and most of the gneiss-migmatite complex transformed into granite-gneisses, granite-migmatites and porphyroblastic microcline granites.

The northeastern part of the Dzirula massif contains Neoproterozoic ophiolite fragments, and is known as the ChorchanaUtslevi Ophiolitic Zone (Gamkrelidze et al., 1981). The ophiolites are spatially related to the gneiss-migmatite complex, and are cut by the Upper Paleozoic microcline granites. A detailed study of this unit (Zakariadze et al., 1998) identified ultra-basic harzburgites that represent melting restites of tholeitic basalt; their Nd model age corresponds to $810 \pm 100 \mathrm{Ma}$. Later study indicated that not only the Chorchana-Utslevi ophiolitic zone overthrust, but the whole gneissmigmatite complex overlies it in the Dzirula massif (Okrostsvaridze, Shengelia, 1996; Shengelia, Okrostsvaridze, 1998).

\section{Field relations and granitoid petrography}

The majority of the gneiss-migmatite complex of the Dzirula massif is constructed of quartz-dioritic gneisses $(\sim 70 \%)$. They are dark gray, medium grained rocks, with occasional plagioclase phenocrysts (4-5 mm). Mineral composition includes plagioclase, biotite, quartz, hornblende; secondary minerals include K-feldspar, muscovite, chlorite and epidote; accessory minerals include apatite, zircon, thorite and ore minerals. Quartz-dioritic gneisses are characterized by numerous oval inclusions of gabbro to diorite composition. Inclusions range between tens of centimeters to one meter and in some cases make $30-35 \%$ of the entire exposure. We consider that the xenoliths represent the restites of basic injections, which made ensialic protolith assimilation and hybridism. 
Cambrian tonalities largest exposures are in the Macharula and Kvirila river gorges where they are exposed over a distance of $800 \mathrm{~m}$. In both sections several tonalitie bodies intruded the gneiss-migmatite complex. The host rock undergoes selective melting and migmatization at the contacts, and biotite gneisses and migmatite inclusions are found in the tonalite intrusive bodies. Late Variscan quartz-muscovitemicrocline aplite and pegmatite veins cut each of these features. The mineral assemblage of unchanged tonalites consists of plagioclases (oligoclase) biotite, quartz, and K-feldspar. Accessory minerals include apatite, zircon, thorite and Fe-Ti oxides. As a result of field and petrographic observation we find that tonalities may be the product of anatectic melting of biotite gneisses of the gneiss-migmatite complex.

Upper Paleozoic microcline granites are widely spread in the Dzirula outcrop and represent the product of the Variscan tectonicthermal events. The gneiss-migmatite complex is saturated with numerous intrusions of these granites. In the northern part of the Dzirula massif, the largest of these granites is exposed; the Rkvia intrusive $\left(\sim 65 \mathrm{~km}^{2}\right)$ has a lens-like form of NW-SE orientation. The intrusion is composed of porphyritic granites with idiomorphic $\mathrm{K}$ feldspars, the main mass of which is in a medium grained massive structure. The main minerals are plagioclase, $\mathrm{k}$-feldspar, quartz, biotite and muscovite; secondary minerals are: muscovite, sericite, chlorite and epidote; accessory minerals are - zircon, apatite, monazite and ilmenite.

In the eastern part of the Dzirula massif, in the Rikoti river gorge, two small intrusives (thickness- $450 \mathrm{~m}$ and $250 \mathrm{~m}$ ) of orthoclase gabbro are presented, which cross cut quartz-dioritic gneisses. Due to their exotic character the investigators called them the rikotites. Their contact zones are intricate because of Alpine tectonic processes, but partial melting products are detected in the approximately 2-meter wide contact zone. Inclusions of $10 \mathrm{~cm}$ to $50 \mathrm{~cm}$ diameters ellipsoid leucocratic quartz-orthoclase are characteristic of rikotites, the number of which decreases from the periphery to the centre. The inclusions are gradually displaced by orthoclase gabbros. Following the field work results, we assume that these acid rocks inclusions are xenoliths
- the product of selection melting which were abducted by the intrusive on its way of moving. We relate gabbros magma enrichment by orthoclase and quartz to these processes.

\section{Geochemistry and geochronology}

Seventy samples of the Dzirula massif granitoids were collected for complex isotopic research. Major element, trace and rare earth element composition have been analyzed. Based on the petrographic and geochemical work, a subset of twenty four samples were analyzed for $\mathrm{Sm}-\mathrm{Nd}, \mathrm{Rb}-\mathrm{Sr}$ and ${ }^{40} \mathrm{Ar}-{ }^{39} \mathrm{Ar}$ isotopic systematics. Sm-Nd and $\mathrm{Rb}-\mathrm{Sr}$ investigations were carried out at the University of California at Berkeley Isotopic Research Centre. ${ }^{40} \mathrm{Ar}^{-}{ }^{39} \mathrm{Ar}$ and major, trace and rare earth element composition determination was done at the laboratories of Dalhousie University (Canada).

Neoproterozoic quartz-dioritic gneisses have an average $\mathrm{SiO}_{2}$ content of $64.08 \%$, with relatively high $\mathrm{Al}_{2} \mathrm{O}_{3}(17.86 \%$ ) (Table 1). In these rocks $\mathrm{Na}_{2} \mathrm{O}(4.16 \%)$ is higher than $\mathrm{K}_{2} \mathrm{O}(2.64 \%)$ and $\mathrm{K}_{2} \mathrm{O} /$ $\mathrm{Na}_{2} \mathrm{O}=0.64$. Quartz-diorite gneisses are metaluminous rocks (Clarke, 1992) and according to A/CNK parameter (1.07) they are I-type (Chappel, White, 1974) or H-type (Castro et al., 1991) granitoids. The $\mathrm{D}_{1}-\mathrm{D}_{2}$ discrimination diagram (Figure 3 ) is consistent, indicating an I-type. REE concentration in quartz-diorite gneisses is relatively low. The trend has weak asymmetry and no expressed Eu negative anomaly (Okrostsvaridze, Clarke, 2003), which shows that in quartzdioritic gneisses magma did not undergo significant fractional crystallization. In quartz-dioritic gneisses $\mathrm{I}_{\mathrm{Sr}}$ parameter is quite relatively constant at 0.7044 ; this low value suggests a mantle source for these rocks (Table 2). In these rocks $\varepsilon \mathrm{Nd}$ parameter varies from 1.76803 to -2.19501 . This shows that they were formed from the protolith which had comparatively low $\mathrm{Sm} / \mathrm{Nd}$ parameters relative to chondrite. The Sm-Nd model age did not show reliable results (2376 $\pm 600 \mathrm{Ma})$ (Table 3), but these results suggest that the protolith may have been middle Proterozoic formations. More reliable results were reached by $\mathrm{Rb}-\mathrm{Sr}$ system, which corresponds to $686 \pm 74 \mathrm{Ma}$.

Table 1. Chemical composition (\%) and some petrochemical parameters of the Dzirula massif granitoids and orthoclase gabbros (rikotites)

\begin{tabular}{|c|c|c|c|c|c|c|c|c|c|c|c|c|c|c|}
\hline Sample & $\mathrm{SiO}_{2}$ & $\mathrm{TiO}_{2}$ & $\mathrm{Al}_{2} \mathrm{O}_{3}$ & $\mathrm{Fe}_{2} \mathrm{O}_{3}$ & $\mathrm{MnO}$ & $\mathrm{MgO}$ & $\mathrm{CaO}$ & $\mathrm{Na}_{2} \mathrm{O}$ & $\mathrm{K}_{2} \mathrm{O}$ & $\mathrm{P}_{2} \mathrm{O}_{5}$ & $\mathrm{D}_{1}$ & $\mathrm{D}_{2}$ & $\mathrm{R}_{1}$ & $\mathrm{R}_{2}$ \\
\hline \multicolumn{15}{|c|}{ Quartz-dioritic gneisses } \\
\hline Dz 10 & 64.44 & 0.84 & 17.69 & 6.46 & 0.07 & 1.53 & 4.55 & 3.96 & 2.08 & 0.28 & 2.3 & -19.4 & 2667 & 1028 \\
\hline Dz 12 & 63.92 & 0.71 & 17.47 & 5.18 & 0.06 & 1.42 & 3.92 & 4.17 & 2.72 & 0.22 & -1.7 & -18.7 & 2517 & 997 \\
\hline Dz 13 & 63.89 & 0.55 & 18.42 & 4.64 & 0.07 & 1.47 & 3.70 & 4.35 & 3.14 & 0.16 & -2.7 & -16.4 & 2660 & 1153 \\
\hline \multicolumn{15}{|c|}{ Tonalites } \\
\hline Dz 31 & 66.67 & 0.77 & 15.83 & 5.99 & 0.08 & 2.44 & 2.57 & 2.99 & 2.92 & 0.92 & 4.9 & -7.4 & 2517 & 520 \\
\hline Dz 32 & 67.83 & 0.69 & 16.29 & 4.40 & 0.08 & 2.00 & 2.63 & 2.85 & 3.72 & 0.31 & 8.1 & -9.3 & 2520 & 490 \\
\hline Dz 44 & 67.09 & 0.69 & 16.18 & 6.87 & 0.08 & 2.60 & 2.32 & 2.86 & 2.71 & 0.06 & 7.4 & -6.4 & 2347 & 533 \\
\hline Dz 45 & 67.36 & 0.63 & 16.37 & 5.62 & 0.09 & 1.36 & 2.04 & 2.84 & 3.71 & 0.08 & 5.9 & 5.7 & 2410 & 628 \\
\hline \multicolumn{15}{|c|}{ Microcline granites } \\
\hline Dz 2 & 72.25 & 0.27 & 15.09 & 2.57 & 0.04 & 0.59 & 1.23 & 3.55 & 3.78 & 0.15 & 10.4 & -5.3 & 2548 & 450 \\
\hline Dz 4 & 71.01 & 0.56 & 16.35 & 2.15 & 0.07 & 1.16 & 1.34 & 2.16 & 3.69 & 0.06 & 8.3 & -2.7 & 2775 & 482 \\
\hline Dz 9 & 74.79 & 0.07 & 14.71 & 1.15 & 0.06 & 0.18 & 0.61 & 3.65 & 4.17 & 0.22 & 14.6 & 2.7 & 2663 & 507 \\
\hline Dz 15 & 75.09 & 0.22 & 15.21 & 1.98 & 0.05 & 0.51 & 1.15 & 3.79 & 3.75 & 0.17 & 5.2 & 4.7 & 2733 & 466 \\
\hline Dz 16 & 71.88 & 0.017 & 15.49 & 1.74 & 0.04 & 0.42 & 1.15 & 3.31 & 5.52 & 0.15 & 13.6 & -5.3 & 2365 & 493 \\
\hline \multicolumn{15}{|c|}{ Orthoclase gabbros (rikotites) } \\
\hline R 20 & 46.6 & 0.964 & 9.87 & 11.75 & 0.21 & 10.84 & 14.95 & 1 & 1.76 & 0.38 & - & - & - & - \\
\hline R 21 & 51.02 & 0.718 & 7.12 & 10 & 0.174 & 11.99 & 15.68 & 1.08 & 1.11 & 0.03 & - & - & - & - \\
\hline R 23 & 50.25 & 0.7 & 6.40 & 9.26 & 0.195 & 11.79 & 17.48 & 1.25 & 0.87 & 0.06 & - & - & - & - \\
\hline R 26 & 51.57 & 0.817 & 16.57 & 8.36 & 0.156 & 4.63 & 7.99 & 2.16 & 2.02 & 0.43 & - & - & - & - \\
\hline
\end{tabular}


Table 2. Chemical composition of Rb, Sr, Sm and Nd (ppm) and some isotopic data of the Dzirula Massif granitoids and orthoclase gabbros (rikotites)

\begin{tabular}{|c|c|c|c|c|c|c|c|c|c|c|}
\hline Sample & $\mathrm{Rb}$ & $\mathrm{Sr}$ & ${ }^{87} \mathrm{Rb} /{ }^{86} \mathrm{Sr}$ & ${ }^{87} \mathrm{Sr} /{ }^{86} \mathrm{Sr}$ & $\mathrm{I}_{\mathrm{Sr}}$ & $\mathrm{Sm}$ & $\mathrm{Nd}$ & ${ }^{147} \mathrm{Sm}^{144} \mathrm{Sm}$ & ${ }^{143} \mathrm{Nd} /{ }^{144} \mathrm{Nd}$ & $\varepsilon N d$ \\
\hline \multicolumn{11}{|c|}{ Quartz-dioritic gneisses } \\
\hline Dz10 & 89.27 & 387.51 & 0.4576 & 0.70872 & 0.70584 & 3.24 & 22.47 & 0.512362 & 0.11998 & -1.76803 \\
\hline Dz12 & 97.64 & 402.23 & 0.5934 & 0.71023 & 0.70441 & 3.96 & 20.38 & 0.512379 & 0.11780 & -1.96703 \\
\hline Dz13 & 110.22 & 416.89 & 0.7476 & 0.71172 & 0.70442 & 4.17 & 18.87 & 0.512071 & 0.12140 & -2.19501 \\
\hline \multicolumn{11}{|c|}{ Tonalites } \\
\hline Dz31 & 116.23 & 213.75 & 1.53879 & 0.72051 & 0.70920 & 6.48 & 38.45 & 0.512062 & 0.10410 & -6.28938 \\
\hline Dz32 & 118.87 & 294.18 & 1.1432 & 0.71757 & 0.70891 & 3.98 & 17.08 & 0.512349 & 0.14394 & -2.87918 \\
\hline Dz44 & 110.20 & 248.86 & 1.2529 & 0.71826 & 0.70877 & 7.10 & 39.63 & 0.512044 & 0.11064 & -6.99145 \\
\hline Dz45 & 89.67 & 290.02 & 1.3833 & 0.71606 & 0.70882 & 9.30 & 48.56 & 0.512070 & 0.11823 & -6.89080 \\
\hline \multicolumn{11}{|c|}{ Microcline granites } \\
\hline Dz2 & 114.99 & 249.60 & 0.98124 & 0.71519 & 0.70722 & 5.86 & 33.29 & 0.51216 & 0.10863 & -4.50135 \\
\hline Dz4 & 153.83 & 74.93 & 1.29801 & 0.71512 & 0.71460 & 8.08 & 45.59 & 0.51191 & 0.10947 & -9.36967 \\
\hline Dz9 & 177.68 & 36.08 & 1.82012 & 0.71783 & 0.70668 & 1.20 & 4.17 & 0.51223 & 0.17722 & -6.92835 \\
\hline Dz15 & 130.40 & 203.49 & 1.72948 & 0.71723 & 0.70671 & 5.08 & 23.20 & 0.51214 & 0.13525 & -6.43603 \\
\hline Dz16 & 155.39 & 250.46 & 1.73452 & 0.71581 & 0.70665 & 3.92 & 23.31 & 0.51227 & 0.10387 & -2.19580 \\
\hline \multicolumn{11}{|c|}{ Orthoclase gabbros (rikotites) } \\
\hline $\mathrm{R} 20$ & 442.21 & 54.82 & 0.35032 & 0.70602 & 0.70497 & 7.06 & 33.62 & 0.51237 & 0.12968 & +0.44803 \\
\hline $\mathrm{R} 21$ & 50.59 & 215.24 & 0.66948 & 0.70715 & 0.70514 & 3.60 & 13.88 & 0.51258 & 0.16417 & -0.26030 \\
\hline $\mathrm{R} 23$ & 257.81 & 123.59 & 0.29257 & 0.70614 & 0.70526 & 6.19 & 26.67 & 0.51258 & 0.14327 & +0.28341 \\
\hline $\mathrm{R} 26$ & 836.14 & 119.42 & 0.40361 & 0.70654 & 0.70533 & 6.88 & 37.17 & 0.51254 & 0.11421 & +0.15332 \\
\hline
\end{tabular}

Proceeding from these data and geological evolution of the region, we can assume that quartz-dioritic gneisses was formed in the Neoproterozoic at the Early Pan-African tectonic-thermal events.

In the Cambrian Tonalites $\mathrm{SiO}_{2}(67.26 \%)$ is higher than in the Neoproterozoic quartz dioritic gneisses, but $\mathrm{Al}_{2} \mathrm{O}_{3}$ is lower $(16.16 \%)$. In these rocks as compared to quartz-dioritic gneisses $\mathrm{Na}_{2} \mathrm{O}$ concentration (2.88\%) is relatively low but $\mathrm{K}_{2} \mathrm{O}$ is quite high (3.26\%). Cambrian tonalites are metaluminous rocks and according to $\mathrm{A} / \mathrm{CNK}$ parameter (1.22) it is S-type granitoids (Okrostsvaridze, Shengelia, 1996). The $D_{1}-D_{2}$ discrimination diagram (Figure 3) is consistent, indicating an S-type. REE concentration is quite high, but with symmetric trends. They are enriched in lanthanides, comparatively poor in heavy REE and weakly expressed Eu minimum, which shows that crystal fractioning was not an important process in the development of these rocks (Okrostsvaridze, Clarke, 2004).

In tonalites $\mathrm{I}_{\mathrm{Sr}}$ parameter varies from 0.7081 to 0.7082 which is a consistent with for the upper crust. The $\varepsilon \mathrm{Nd}$ parameter ranges from -2.8792 to -6.8906 (Table 2); suggesting a strong influence of upper crustal partial melts.

$\mathrm{Rb}$-Sr isochrones of tonalites showed an age of 538 \pm 53 Ma which corresponds to Cambrian age. Biotite samples were also analyzed by ${ }^{40} \mathrm{Ar}-{ }^{39} \mathrm{Ar}$ method gave an Upper Paleozoic age of $306 \pm 2$ (Table 3).

Table 3. Isotopic Ages (Ma) of the Dzirula massif Granitoid and rikotites (orthoclase gabbros)

\begin{tabular}{|l|c|c|c|c|}
\hline Rock name & $\begin{array}{c}\text { Quartz-dioritic } \\
\text { gneisses }\end{array}$ & Tonalites & $\begin{array}{c}\text { Microcline } \\
\text { granites }\end{array}$ & Rikotites \\
\hline $\begin{array}{l}\text { Sm-Nd } \\
\text { method }\end{array}$ & $2370 \pm 600$ & - & - & $278 \pm 48$ \\
\hline $\begin{array}{l}\text { Rb-Sr } \\
\text { method }\end{array}$ & $686 \pm 74$ & $538 \pm 53$ & $331 \pm 21$ & $211 \pm 11$ \\
\hline $\begin{array}{l}{ }^{40} \mathrm{Ar}-{ }^{39} \mathrm{Ar} \\
\text { method }\end{array}$ & $\begin{array}{c}309 \pm 5 \\
\text { (biotite) }\end{array}$ & $\begin{array}{c}306 \pm 2 \\
\text { (biotite) }\end{array}$ & $\begin{array}{c}303 \pm 4 \\
\text { (biotite) }\end{array}$ & $\begin{array}{c}219 \pm 4 \\
\text { (hornblende) } \\
217 \pm 3 \\
\text { (biotite) }\end{array}$ \\
\hline
\end{tabular}

Proceeding from these data, we assume they tonalities could have been generated at Late Pan-African tectonic-magmatic events by melting of metapelites of the gneiss-migmatite complex.

Late Paleozoic Microcline granites have an average $\mathrm{SiO}_{2}$ of $73.00 \% ; \mathrm{Al}_{2} \mathrm{O}_{3}$ is the lowest among the Dzirula massif granitoids $(15.31 \%)$. Alkalinity is increased $\left(\mathrm{Na}_{2} \mathrm{O}=3.49 ; \mathrm{K}_{2} \mathrm{O}=4.18\right)$ and $\mathrm{K}_{2} \mathrm{O} /$ $\mathrm{Na}_{2} \mathrm{O}$ parameter is equal to 1.20 which is typical upper crust granitoid data (Table 1).

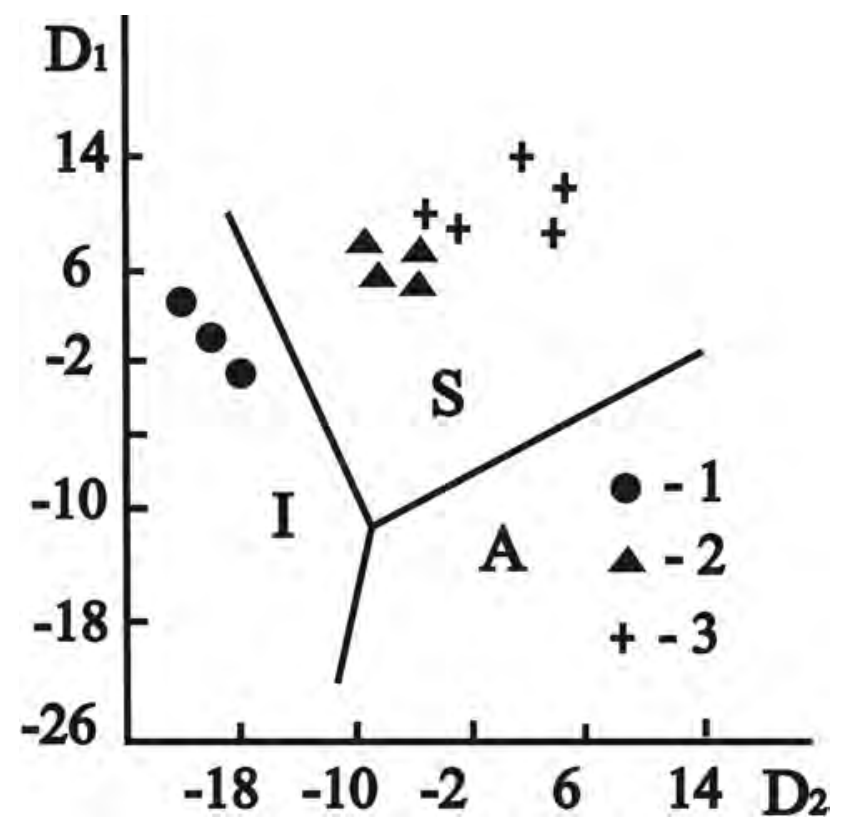

Figure 3. $D_{1}-D_{2}$ Discrimination diagram (Hassan, McAllister, 1992) for the Dzirula massif granitoids. Fields: I - type granites; $S$ - type granites; $\mathrm{A}$ - type granites. $\mathrm{D}_{1}=0.76 \mathrm{Al}_{2} \mathrm{O}_{3}+2.91 \mathrm{MnO}-1.93 \mathrm{Na}_{2} \mathrm{O}+$ $1.95 \mathrm{~K}_{2} \mathrm{O}-18.50 \mathrm{P}_{2} \mathrm{O}_{5} ; \mathrm{D}_{2}=0.37 \mathrm{Al}_{2} \mathrm{O}_{3}+7.25 \mathrm{TiO}_{2}-54.08 \mathrm{MnO}$ 4.28Na $20-0.55 \mathrm{~K}_{2} \mathrm{O}+45.81 \mathrm{P}_{2} \mathrm{O}_{5}$. Conventional signs: 1 - quartzdioritic gneisses; 2 - tonalities; 3 - microcline granites. 
Upper Paleozoic microcline granites are metaluminous rocks (A/ CNK =1.42) and according to it is S-type (Chappel, White, 1974) granitoids. The $\mathrm{D}_{1}-\mathrm{D}_{2}$ discrimination diagram is consistent, indicating an S-type (Figure 3).

REE distribution in microcline granites are characterized by sharp asymmetry; they show lanthanides high concentration and heavy REE low concentration. They have sharply expressed Eu minimum, which show that intensive crystal fractionation took place in magmatic system (Okrostsvaridze, Clarke, 2004). The $\mathrm{I}_{\mathrm{Sr}}$ has a very wide range, from 0.70667 to 0.71460 . This range suggests extensive incorporation of upper crustal rocks. eNd parameter ranges from -2.19589 to -9.36967; it shows that they were generated by melting of upper crust rocks.

$\mathrm{The} \mathrm{Rb}-\mathrm{Sr}$ isotopic age of microcline granites corresponds to $351 \pm 21 \mathrm{Ma}$ (Tab.3). This is Early Carboniferous, correspondingly, the activity appears to be associated with Variscan tectono-thermal events. In microcline granites (sample Dz2, Dz9, Dz16) muscovite isotopic age was determined using ${ }^{40} \mathrm{Ar}-{ }^{39} \mathrm{Ar}$ method which is identical nearly in all samples and on average equals to $303 \pm 4 \mathrm{Ma}$, which, like the Tonalite ${ }^{40} \mathrm{Ar}^{39} \mathrm{Ar}$ data, also corresponds to Late Variscan.

Rikotites (orthoclase gabbros) represent protolith rocks which were low in $\mathrm{Al}_{2} \mathrm{O}_{3}, \mathrm{Fe}_{2} \mathrm{O}_{3}, \mathrm{~K}_{2} \mathrm{O}$ and high in $\mathrm{CaO}$ and $\mathrm{MgO}$ composition. $\mathrm{Rb}-\mathrm{Sr}$ data of rikotites show $211 \pm 11 \mathrm{Ma}$. Same date of this intrusive was approximately by hornblende ${ }^{40} \mathrm{Ar}-{ }^{39} \mathrm{Ar}$ which corresponds to $219 \pm 4 \mathrm{Ma}$ and by biotite dating using the same method in this intrusive - $217 \pm 3 \mathrm{Ma}$ (Table 3). The $\mathrm{Rb}-\mathrm{Sr}$ isotopic system in rocks is closed at $600-700^{0} \mathrm{C} ;{ }^{40} \mathrm{Ar}-{ }^{39} \mathrm{Ar}$ system in hornblendes at 450 $500^{\circ} \mathrm{C}$; in biotites $300-350^{\circ} \mathrm{C}$. From this we can conclude, that the results are in good correlation with each other and indicate ricotite intrusion took place Upper Triassic during the Cimmerian tectonicthermal events, approximately in the interval of 210-220 Ma.

\section{Summary of Geochemistry Findings}

The geodynamic regime of formation of the Dzirula massif granitoids can be assessed with the $\mathrm{R}_{1}-\mathrm{R}_{2}$ multipartite diagram (Figure 4), quartz-dioritic gneisses figure points are located within pre-plate Collision granitoids field, while tonalites and microcline granites -

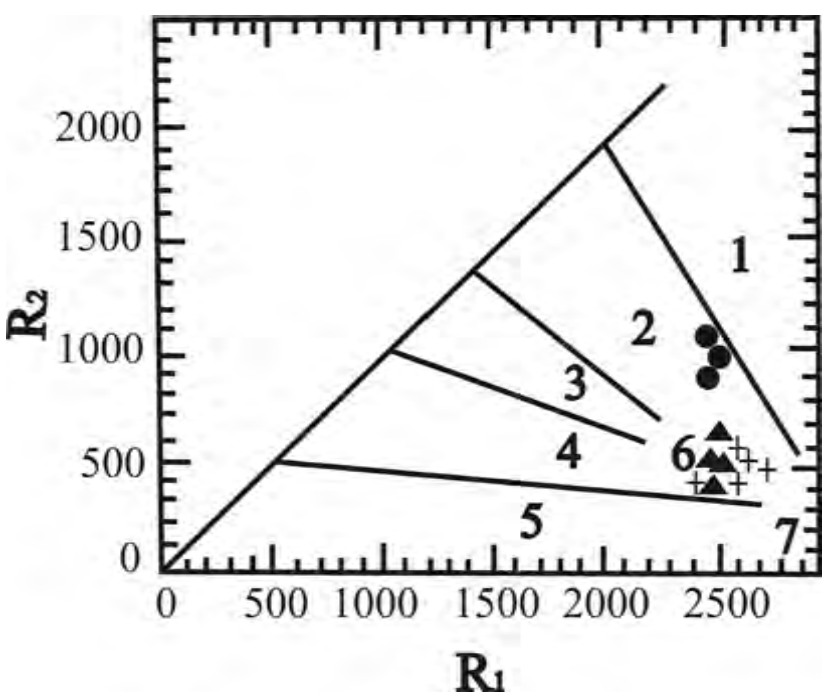

Figure 4. $R_{1}-R_{2}$ discrimination diagram (Bachelor, Bowden, 1985) for the Dzirula massif granitoids $R_{1}=4 \mathrm{Si}-11(\mathrm{Na}+\mathrm{K})-2(\mathrm{Fe}+\mathrm{Ti})$; $R_{2}=6 C a+2 M g+A l$. Conventional signs are identical to figure 3. within the syn-collision. The petrochemical investigation carried out showed, that the Dzirula massif granitoids are genetically different from each other. Quartz-dioritic gneisses belong to metaluminous Itype granites, which were formed in the volcanic arc geodynamic regime and in which magma crystal fractioning didn't take place. Tonalites and microcline granites represent petrochemically similar formations and belong to S-type paraluminous granites which were formed at syn-collision stage evolution of the orogen evolution.

On the $\varepsilon N d-\mathrm{I}_{\mathrm{Sr}}$ isotopic diagram quartz-dioritic gneisses figures points actually do not appear in the field of crust formations and only tonalities and microcline granites figure points follow the upper crust trend (Figure 5). $\varepsilon N d$ - Intrusive age (Ma) relation diagram shows clearly, that all the granitoid figure points investigated by us are located in the field of Phanerozoic crust (Figure 6), which clearly shows, that the Dzirula massif continental crust is Phanerozoic formation. According to granitoid petrogenetic types, isotopic age and $\varepsilon \mathrm{Nd}$ parameters it should be treated as typical Tethyside or collisional orogen (Windley, 1996).

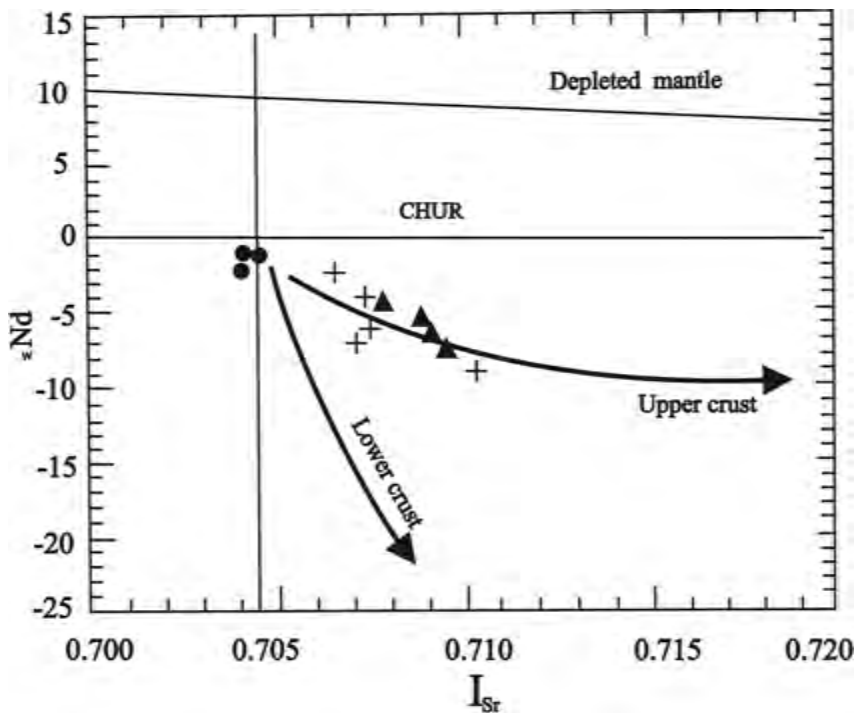

Figure 5. $\varepsilon N d-I_{S r}$ isotopic diagram (Jahn et al., 2000) for the Dzirula massif granitoids. Conventional signs are identical of figure 3.

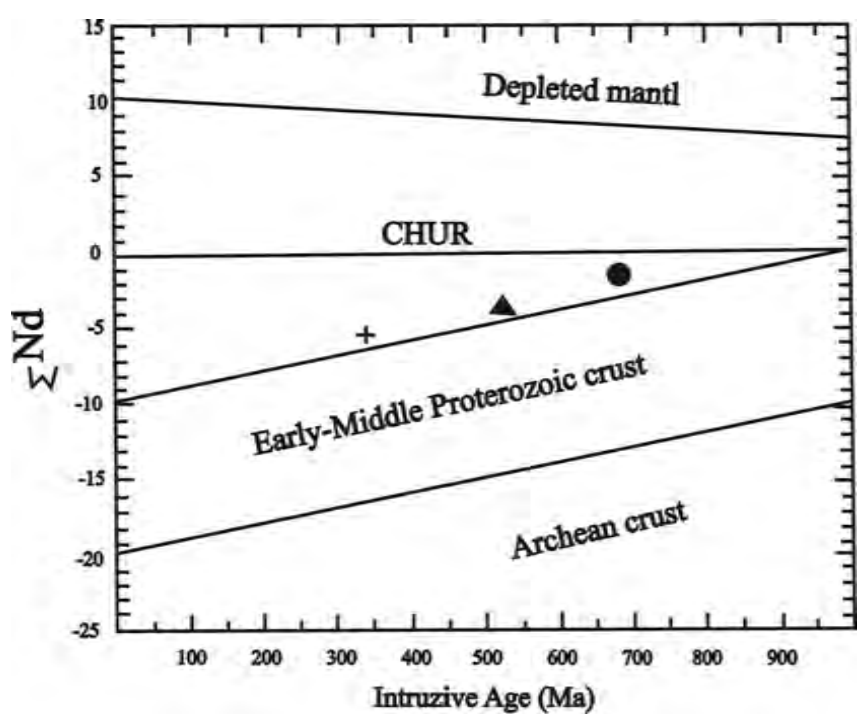

Figure 6. $\varepsilon N d-I_{S r}$ intrusive age (Ma) (Jahn et al., 2000) for the Dzirula massif granitoids. Conventional signs are identical of Figure 3. 


\section{Geodynamic Evolution of the Region}

The geodynamic evolution of the Caucasian orogen, based on geological, paleofacies, paleobiogeographic and paleomagnetic data, centers on the closing of the Tethys oceanic basin at the end of the Alpine cycle as a result of collision of the Afro-Arabian and Eastern European plates (Gamkrelidze, 1991; 1997; Stampfli, Borel, 2002, Raumer et al., 2003). The Inner Caucasian Microplate, of which the Dzirula massif is a part, in these models is treated as microcontinent, island arc or terrane, which was situated in the inner oceanic portion of Tethys. Its genetic relation with any of the continental plates is not well understood. The new tectonic, petrogeochemical and isotopic data obtained from the Dzirula massif gave us an opportunity to constrain the relationship.

Relying on existing information and the data in this paper suggests that the Dzirula massif represents a vertically accretion structure which is constructed of two large formations: Gondwanaderived gneiss-migmatite complex (upper) and ensialic island arc (lower) (Figure 7).

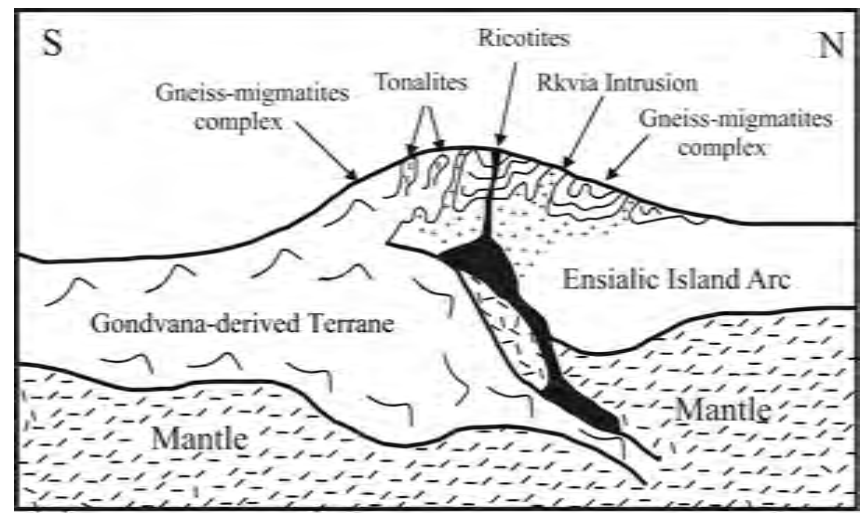

Figure 7.N Hypothetical geological cross section through the Dzitula massif. It is shown on the figure how gneiss-migmatite complex is overlaying ensialic island arc and how base granitoid magma sources are generated. Base magma generation possible model is shown by dark color.

The interrelation of granitoid genetic types and the geodynamic evolution of the region support this structure. In addition, the gneissmigmatite complex is similar to the Arabian Plate Northern edge in age, composition and construction (Marzouki, Fyfe, 1979; Kroner, Stern, 2008). These authors indicate that the Northern part of Arabian Plate, situated to the south of the Inner Caucasian Microplate, represents a mosaic of microcontinents which were connected by PanAfrican tectono-thermal events. Most are characterized by similar composition and tectonic development history to the Dzirula massif gneiss-migmatite complex. The intensive injection of the mantle material, metamorphism, ultrametamorphism and granite-forming processes were of the same character and took place in the intervals of 700-450 Ma. The Pan-African tectonic-thermal events at this time are characterized by a transitional regime, namely, the older inner plate processes are substituted by younger (Phanerozoic) plate edge regimes. Our data indicate that the gneiss-migmatite complex of the Dzirula massif is likely a Gondwana-derived terrane part and separated from the Arabian plate northern edge during the opening of the PalaeoTethys.

To make the idea more clear and convincing we will cite a comparison. The Tsakhkuniats massif, which reveals great similarities with Dzirula massif by its tectonic construction, composition and isotopic parameters, is exposed in the South of the Dzirulla massif, within the borders of Iran-Afganian terrane of Gondwanan origin. The above mentioned massif, as well as Dzirula, is constructed of the Neoproterozoic gneissic metabasalts-migmatites (Hancavan complex), which is obducted on gneiss-paraschist (Arzacan complex). The Hancavan Complex as well as Dzirula massif gneiss-migmatite complex also contains lenses of opiolitic serpentinites and is crossed by quartz-dioritic gneisses intrusive; its the $\mathrm{Rb}-\mathrm{Sr}$ isotopic age is $685 \pm 77 \mathrm{Ma}$ and the Isr=0.703361 (Agamalian, 2004). The age of the Dzirula massif quartz-dioritic gneisses determined by the same method, corresponds to $686 \pm 74 \mathrm{Ma}$ and the $\mathrm{Isr}=0.70489$. So, we can detect many similarities between these two massifs and proceeding from the geodynamic evolution analysis of the region, they are most likely to contains same Precambrian platform relics.

\section{Discussion}

This work has identified four distinct granitoid types in the Dzirula massif, including their spatial relationships, intrusion history, and ages. These data, combined with an understanding of the regional geodynamics, provides an understanding of granitoid melt generation and the evolution of the continental crust in the Dzirula Massif.

The Neoproterozoic gneiss-migmatite complex is the most widely distributed, and occupy the upper plate of the structure. This unit is composed of quartz-dioritic gneisses of I or H-type granitoids. The average isotopic parameters of these rocks $\left(\mathrm{I}_{\mathrm{Sr}}=0.7044 \pm 0.0066 ; \varepsilon \mathrm{Nd}\right.$ $=-1.976692$ ) show that they belong to juvenile crust with a high percent of mantle component. The migmatite complex appears to have formed by partial melting of a subcontinental lithosphere by mantlederived magmas. The age of quartz-diorite gneiss crystallization is $686 \pm 74 \mathrm{Ma}$ (Rb-Sr method), which corresponds to the Early PanAfrican tectonic-thermal events.

The tonalites have a crystallization age of $538 \pm 33 \mathrm{Ma}(\mathrm{Rb}-\mathrm{Sr}$ age) which corresponds to Late Pan-African tectonic-thermal events. The tonalites are more evolved than the gneiss, being $\mathrm{S}$ type granitoids with higher REE concentrations. The tectonic discrimination diagrams indicate the syn-collisional granite field. The isotopic composition of the tonalites indicates a greater upper crustal character compared to the gneiss-migmatite complex $\left(\mathrm{I}_{\mathrm{Sr}}=0.7087 \pm 0.0011 ; \varepsilon \mathrm{Nd}=\right.$ $-5.762702)$. The microcline granites have an age of $351 \pm 21 \mathrm{Ma}(\mathrm{Rb}-$ $\mathrm{Sr}$ method), corresponding to the Variscan tectonic-thermal events. The gneiss-migmatite complex is intruded by the microcline granites at this time. These rocks are much more evolved than either the gneissmigmatite or the tonalites. The microcline granites are biotiticmuscovite peraluminous $S$ type formation and in tectonic discrimination diagrams its plots are in the syn-collision granite fields. The isotopic composition of the microcline granites also indicates a more developed continental crust. The $\mathrm{I}_{\mathrm{Sr}}$ of these rocks ranges between 0.70667 and 0.71460 , and $\varepsilon N d$ from -2.19589 to -9.96967 .

Thus by the late Variscan, the crust of the Dzirula massif has evolved from a primitive composition to one more characteristic of more evolved continental crust. This development occurred during cycles of tectonic-thermal activity that lasted from the upper Proterozoic to the upper Paleozoic. As a result of these cycles, the ensialic protolith $\mathrm{S}$ type Upper Paleozoic microcline granites intrude into the mantle-crust hybrid I type Neoproterozoic gneiss-migmatite complex. Based on the geodynamic setting, the gneiss-migmatite 
complex was overthrust onto the protolith of the microcline granite, and part of the ensimatic terrane subducted under this protolith (Figure 7). This collision led to release of water from the subducted terrane led to partial melting of the microcline granite protolith and formation of the granitoid melt which intruded into the overlying gneiss. This explanation is further supported by the presence of ophiolite fragments in the northern part of the Dzirula massif.

The fourth magmatic rock in the Dzirula massif is the rikotites (orthoclase gabbros). The age of the Rikotites by Rb-Sr method, the whole rock - $211 \pm 11 \mathrm{Ma} ;{ }^{40} \mathrm{Ar}-{ }^{39} \mathrm{Ar}$ method hornblende - 219 $\pm 4 \mathrm{Ma}$; by ${ }^{40} \mathrm{Ar}-{ }^{39} \mathrm{Ar}$ method - biotite is $217 \pm 3 \mathrm{Ma}$. The results indicate that the rikotites intruded into the Dzirula massif during the Upper Triassic, corresponding to the Cimmerian tectonic-thermal events. The rikotites, according to all data, belong to island arc formations that collided with the Dzirula massif area. The rikotites contain orthoclase and are potassium rich. The exotic composition of the rikotites provides further clues about the development of the Dzirula massif. The rikotites appear to have a mantle source, and partial melting and incorporation of the potassium-bearing granites or their protolith appear to have led to the potassium enrichment of the rikotites.

\section{Conclusions}

Field, petrochemical, isotopic, and geochronological investigation of the granitoids of the Dzirula massif illustrate continental crust forming processes from Upper Proterozoic to Upper Paleozoic. The formation of the continental crust in this area was episodic, occurring during three phases of tectono-magmatic events.

The data in this study also constrain the geodynamic history of the Inner Caucasian Microplate. These processes occurred in the closing process of Palaeo-Tethys and the opening of Meso-Tethys. Within the Dzirula massif, a Gondwana-derived Proterozoic gneissmigmatite complex is situated obductively on ensialic island arc. In this Variscan collision-accretion structure, the crustal thickening and released water caused partial melting of the ensialic island arc, thus generating the microcline granites, which intruded the overlying gneiss-migmatite complex. By the end of this process, the Dzirula massif resembled typical continental crust. Later, in the Upper Triassic, the structure was further intruded by potassium rich gabbros (rikotites). Later, during the Alpine tectonic-thermal processes the Inner Caucasian Microplate merged with the Euro-Asian continental southern active edge.

\section{Acknowledgements}

The authors would like to express their gratitude to Professor D.B. Clarke from Dalhousie University (Canada), thanks to his assistance it was possible to conduct analytical work both at Berkeley University Isotopic Research Centre (USA) and at Dalhousie University. This work was partially supported by a NATO Science for Peace Grant, which is gratefully acknowledged. The International Lithosphere Program (ILP) provided a platform for this interdisciplinary study.

\section{References}

Agamalian, V., 2004, The Lesser Caucasus Earth Crust formation and evolution in the collision zone of Palaeo-Tethys. Proceedings of the $5^{\text {th }}$ International Symposium on Eastern Mediterranean Geology, pp. 17-20.
Allegre, C.I., Ben Othman, D., 1980, Nd-Sr Relationship in Granitoid Rocks and Continental Crust development: a chemical approach to Orogenesis. Nature, v. 286, pp. 335-343.

Bachelor, R.A. and Bowden, P., 1985, Petrogenetic interpretation of granitoiod rock series using multication parameters. Journal of Chemical Geoogy, v. 48 , pp. 43-55.

Castro, A., Moreno-Ventas, J. and De La Rosa, J.D., 1991, H-type (hybrid) granitoids: A proposed revision of the granite-type classification and nomenclature. Earth Science Review, v. 3, no. 4, pp. 237-253.

Chappel, B.W., White, A.Y.R., 1974, Two contrasting Granite types. Journal Pacif. Geology, no. 8, pp. 173-174.

Clarke, D.B., 1992, Granitoid Rocks. London: Blackwell. 283 p.

Clarke, D.B., Chatterjee, A.K. and Giles, P.S., 1993, Petrochemistry, tectonic history, and Sr-Nd systematic of the Liscomb Complex Meguma Lithotectonic Zone, Nova Scotia. Canadian Journal of Earth Science, no. 30, pp. 449-464.

Collins, W.J., 1998, Evolution of Petrogenetic model for Lachlan Fold Belt granitoids: implication for crustal architecture and tectonic models. Australian Journal Earth Science, v. 45, pp. 83-500.

Daga, M.M., Rao, D.R. and Rai, H., 2010, Granite Magmatizm and Crustal Evolution of the Shyok-Darbuk corridor of NE Ladakh, India. Episodes, v. 33, no. 3, pp. 183-199.

DePaolo, D.J., Linn, A.M. and Solubert, G., 1991, The continental crust age distribution: methods of determining mantle separation age from Sm$\mathrm{Nd}$ isotope data and application to the south-western United States. Journal Geophysical Research, no. 96, pp. 2071-2088.

Gamkrelidze, I.P., 1997, Terrane of the Caucasus and adjacent areas. Bulletin Academy of Science Georgia, v. 155, no.3, pp. 75-81.

Gamkrelidze, I.P., Dumbadze, G.D. and Kekelia, M.A., 1981, Ophiolites of the Dzirula massif and problem of Paleotethyse in Caucasus. Geotectonic, no. 5, pp.23-33.

Gamkrelidze I.P. and Shengelia D.M., 2005, Precambrian-Paleozoic regional metamorphism, granitoid magmatism and geodynamics of the Caucasus. M: Scientific World, 458 p.

Hassan, H.H. and McAllister, A.L., 1992, An integrated geological, geochemical investigation of uranium metallogenesis in selected granitic plutons of the Miramichi Anticlinorium, New Brunswick. Canadian Journal of Earth Science, no. 13, pp. 91-115.

Jahn, B., Wu, F. and Chen, B., 2000, Massive granitoid generation in Central Asia: Nd isotope evidence and implication for continental growth in the Phanerozoic. Episodes, v. 23, no. 2, pp. 82-92.

Marzouki, F. and Fyte, W.S., 1979, Pan-African plates: Additional evidence from igneous events in Saudi Arabia. Contribution to Mineralogy and Petrology, v. 60, no.3, pp. 219-224.

Okrostsvaridze, A.V. and Shengelia, D.M., 1996, New Data on the formation of microcline granites of Dzirula salient. Bulletin Academy of Science Georgia., v. 14, no. 1, pp. 93-95.

Okrostsvaridze, A.V. and Clarke D.B., 2003, The First Data on the Investigation of Sm-Nd and Rb-Sr Izotopic Systems of the Dzirula Salient Gneisses-Quartz-Diorites of the Black Sea - Central Transcaucasian Terrane. Bulletin Academy of Science Georgia, v. 168, no. 2, pp. 281-285.

Okrostsvaridze, A.V. and Clarke D.B., 2004, New data of isotopic investigation of magmatic rocks of Dzirula salient of Caucasian Inner Massif. Journal Rep. Russian Academy of Sciences, v. 398, no. 1, pp. 117-121.

Samson S.D. and Patchett P.J., 1991, The Canadian Cordillera as a modern analogue of Proterozoic crustal growth. Australian Journal of Earth Sciences, no. 38, pp. 595-611.

Roumer, I.F., Stampfly, M. and Bussy, F., 2003, Gondwana-derived microcontinents - the constituent of the Variscan Alpine collisional orogens. Journal of Tectonophysics, no. 365, pp. 7-22.

Shengelia, D.M. and Okrostsvaridze, A.V., 1998, New data on the construction of Dzirula salient of Pre-Alpine Georgian block. Journal Rep. Russian Academy of Sciences, v. 559, no. 6, pp. 800-803.

Shengelia, D.M. and Okrostsvaridze, A.V., 1998, New data on the construction of Dzirula salient of Pre-Alpine basement of Georgian block. Journal Rep. Russian Academy of Sciences, v. 559, no. 6, pp. 800-803. 
Stampli, G.M., Borel, G.D., Cavazza, W., Mosar, J. and Ziegler, P.A., 2001, Palaeotectonic and paleogeographic evolution of the Western Tethys and Peri-Tethyan domain. Episodes, v. 24, no. 4, pp. 222-228.

Stern, R.J., 2008, Neoproterozoic crustal growth: The solid Earth system during a critical episode of Earth history. Gondwana Research, v. 14, issues 1-2, pp. 33-50.

Taylor, S.R. and McLennan, S.M., 1985, The continental crust: its evolution

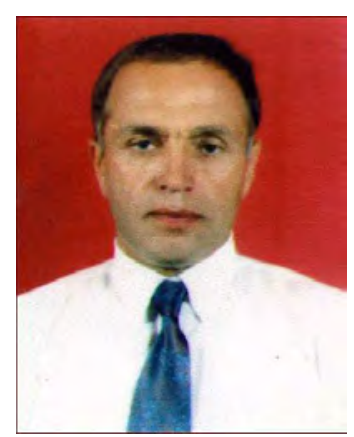

Avtandil Okrostsvaridze received his degree of the Doctor of Geological Sciences in 1995 at the Geological Institute of the Georgian Academy of Sciences. His main scientific interests comprises granitoid magmatism, problems of the continental crust evolution and metallogenesis in orogenic systems. At present he works as a professor and head of the Geological department at the Ilia State University (Georgia, Tbilisi) and as scientific supervisor at the Mining Corporation "Golden Fleece". and composition. London: Blackwell, 312 p.

Windley, B., 1996, The evolving Continent, $3^{\text {rd }}$ edition. Chichester: John Wiley and Sons, $526 \mathrm{p}$

Zakariadze, G.S., Karpenko, S.F. and Bazilev, B.A., 1998, Petrology, geochemistry and Sm-Nd izotopic age of Pre-Late-Hercynian paleooceanic complex of Dzirula salient of Transcaucasian massif. Journal of Petrology, v. 6, no. 4, pp. 422-444.

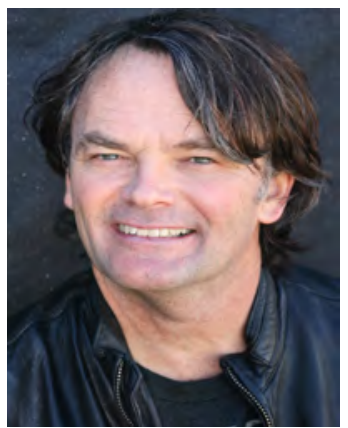

Daniel Tormey has Ph.D. in Geology and Geochemistry, Massachusetts Institute of Technology. He studies the growth of the continental crust through the geochemistry and volcanology of convergent margin and extensional settings. He conducts volcanic, seismic, and landslide hazard assessment and mitigation planning. He is an expert in water and energy, conducting projects in sediment transport, hydrology, water supply, and water quality, as well as the environmental aspects of energy and energy development. 